\title{
LKKA DE்STYTOJŲ VERTYBINIŲ ORIENTACIJŲ IR POŽIŪRIO I AKADEMIJĄ RAIŠKA AUKŠTOJO MOKSLO SANTYKIŲ SU VISUOMENE RAIDOS KONTEKSTE
}

\author{
Saulius Šukys, Kęstutis Kardelis, Albertas Skurvydas
}

Lietuvos kūno kultūros akademija, Kaunas, Lietuva

\begin{abstract}
Saulius Šukys. Socialinių mokslų daktaras. Lietuvos kūno kultūros akademijos Kinantropologijos ir sporto raidos katedros lektorius, Socialinių kūno kultūros ir sporto tyrimų laboratorijos mokslo darbuotojas. Mokslinių tyrimų kryptis — sportinės veiklos poveikis vaikų ir paauglių elgsenai.
\end{abstract}

\begin{abstract}
SANTRAUKA
Šio tyrimo metu analizuoti dèstytoju vertybinių orientaciju ir požiūrio į aukštają mokykla ypatumai. Norint išnagrinèti keliama probleminį klausima, buvo apklausta 90 Lietuvos kūno kultūros akademijos dèstytojų. Ju vertybinèms orientacijoms nustatyti naudota 10 vertybiu (iš viso 45) grupiu skalè. Tiriant déstytoju požiūri í aukštaja mokykla, buvo vertinami tokie ju požiūrio komponentai kaip institucijos visuomeninis vaidmuo miesto ir šalies kontekste, jos valdymo bei vadovybès atsakomybé, dèstytoju tarpusavio bendravimas, akademiniu ir mokslo žiniu panaudojimo galimybès, akademiniu vertybiu nuostatos. Buvo nustatoma desstytoju identifikavimosi su aukštaja mokykla raiška.

Išanalizavus vertybiniu orientaciju duomenis matyti, kad akademijos dėstytojai gyvenimo prioritetais laiko išmintinguma, pažiūru platuma ir gebèjima atlikti užduotis. Požiūrio ỉ akademija ir akademines vertybes rezultatai parodè, kad dèstytojai gerai supranta moksliniu tyrimu ir mokslininku rengimo svarba, pritaria, jog labai svarbu ruošti gebančius darbo rinkoje prisitaikyti specialistus, daugiau nei puse darbuotoju yra skaitę ar dalyvavę seminaruose kitose aukštosiose mokyklose. Dauguma déstytoju palankiai vertina akademija ir nèra jai abejingi, tačiau kur kas mažiau yra patenkinti darbo salygomis ir bendravimu su studentais. Pastebèta palankesnio požiūrio i akademija priklausomybe nuo pedagoginès mokslinès kvalifikacijos. Taigi galima daryti išvada, kad moksliniu tyrimu plètra ir mokslininku rengimas yra pagrindiniai akademijos prioritetai.
\end{abstract}

Raktažodžiai: aukštoji mokykla, dėstytoju vertybinès orientacijos, požiūris i aukštaja mokyklą ir akademines vertybes.

\section{IVADAS}

$\mathrm{P}$ asaulyje vykstantys globalizacijos procesai lemia ivvairių šalių aukštojo mokslo sistemos pokyčius, tarp ju ir akademiniu vertybių. Vis didesnis dėmesys skiriamas universitetų visuomeniniam vaidmeniui. Pavyzdžiui, nurodoma, kad universitetai, noredami išlikti, turi pademonstruoti aiškias verslumo ypatybes ir kurti tokius produktus, kurie būtų konkurencingi žinių rinkoje (Markevičienè, 2004).

Tradiciškai aukštojo mokslo ir visuomenès santykis suprantamas kaip tam tikrų universiteto paslaugu teikimas visuomenei: jaunu specialistų rengimas, fundamentinių ir taikomuju tyrimų atlikimas, socialinių pokyčių stimuliavimas ir kt. Visgi, vystantis žinių visuomenei, atsiranda naujos aukštojo mokslo ir visuomenės sąsaju dimensijos - atliktų tyrimų rezultatų pardavimas ir paslaugu klientams už universiteto sienu teikimas. Kartu kinta ir požiūris i aukštaji mokslą. I ji pradedama žiūrèti kaip į visuomenès gerovę ir šalies ekonominę plètrą stimuliuojantị veiksni (Verri, 2003; Bridges, 2004). Pasak B. Janiūnaitės 
ir D. Gudaitytės (2003), progresas vyks ir žmonių kasdienis gyvenimas gerès tik tuo atveju, jeigu sąsaja tarp aukštojo mokslo ir visuomenès bus suprantama kaip abipusė ir abipusiškai pasitikint. Tai rodo, kad visuomenejje vykstantys globalizacijos procesai skatina iš naujo permąstyti aukštosios mokyklos ir mokslo, kaip žinių industrijos, elementus. Daugiau démesio pradedama skirti profesiniam orientavimui, kuriamos naujos mokymo ir mokslo paradigmos, aukštojo mokslo formos. Kartu atkreipiamas dèmesys į akademinio darbo pokyčius. Čia pabréžiama glaudesné dėstomų dalykų programų sąsaja su studentu ir rinkos poreikiais, mažiau svarbia tampa dėstytojo paskaitu, kaip pagrindinès žinių perdavimo formos, svarba. Didesnis dėmesys skiriamas studentų savarankiškam darbui ieškant atsakymų i probleminius klausimus, tam tikros srities igūdžių ugdymui (Verri, 2003; Scott, 2003).

Praeito šimtmečio antroje pusejje Vakarų šalyse išryškejjo dar viena aukštojo mokslo tendencija studentų skaičiaus didèjimas ir vis didesnè valstybės kontrolè (Želvys, 2003). Savaime suprantama, kad universitetai niekada neturèjo visiškos autonomijos. Visais laikais jie atsirasdavo visuomeninę bei politinę galią turinčių institucijų dėka, taigi yra veikiami socialiai (Peterson, 2003). Suprantama, kad valstybè, didesnes lëšas skirdama mokslui, labiau stengiasi kontroliuoti jų panaudojimą. Kita vertus, vis dažniau akcentuojama, kad aukštosios mokyklos turètu gebėti ir pačios užsidirbti.

Suminèti pokyčiai aukštojo mokslo santykių su visuomene kontekste, be abejo, aktualūs ir Lietuvai. Visgi jeigu Vakarų Europoje ir kitose šalyse šie pokyčiai vyksta natūraliau, t. y. juos skatina poreikis būti pirmaujančiais mokslo srityje (nors pastaruju metų tendencijos vertinant šią perspektyvą, ypač norą pasivyti JAV, darosi vis niūresnès), tai posovietinėse šalyse tie pokyčiai yra neišvengiami norint perimti Vakarų pasaulyje egzistuojančias švietimo ir mokslo tradicijas arba, kitaip tariant, isilieti i globalias švietimo ir mokslo erdves.

Šių aukštojo mokslo pokyčių igyvendinimo procese ryškejja ir studijų kokybès svarba, kurios vertinimas pastaruoju metu susilaukia vis didesnio dèmesio. Antai, norint garantuoti aukštojo mokslo kokybę, diegiamos naujos sistemos bei informacinès technologijos, kartu nepamirštant ir mokymosi kokybès (Gynnild, 2003). Nemažiau svarbios šiame procese turètų būti ir universiteto dèstytojų, kaip studijų ir mokslinių tyrimų organizatorių ir vykdytojų, subjektyviai išgyventos nuostatos dèl studijų proceso, jų vertybès. Tokie psichosocialiniai studijų procesą bei tyrimus lemiantys veiksniai gali paveikti studiju kokybę, kartu ir aukštojo mokslo santykių su visuomene pokyčių igyvendinimą. Visgi panašaus pobūdžio darbų, kuriuose būtų sprendžiami probleminiai klausimai, susiję su universiteto dėstytojų vertybinėmis orientacijomis ir jų nuostatomis dèl aukštosios mokyklos bei akademiniu vertybių, mūsų universitetų praktikoje aptikti neteko. Kiek daugiau analizuotos dèstytojų nuostatos dèl studijų kokybės (Valiuškevičiūtė ir kt., 2004). Tai ir paskatino planuoti ši tyrima, kurio pradžioje kèlėme prielaida, kad dėstytojų požiūris į aukštają mokyklą ir akademines vertybes priklausys nuo ju pedagoginès mokslinès kvalifikacijos.

Tyrimo objektu pasirinkę studijų procesą, o jo priklausomais kintamaisiais, atitinkančiais tiriamaji dalyką (dėstytojų vertybines orientacijas ir jų požiūri i aukštają mokyklą), siekème tikslo - atskleisti šių kintamuju raišką. Taip pat aiškinomės tokius jų nuostatų dẻl aukštosios mokyklos komponentus kaip požiūris i akademines vertybes, santykių su bendradarbiais, lojalumo ir identifikacijos su institucija raišką.

\section{TYRIMO METODIKA}

Tiriamieji. Tiriamają imtị sudare 90 (63\%) Lietuvos kūno kultūros akademijos dèstytojų. Likusi dalis dėstytojų, nors jiems ir buvo priminta, nepanoro dalyvauti apklausoje. Toks apklaustųju procentas yra artimas optimaliam (Kardelis, 2002), tad tyrimo rezultatus būtų galima apibendrinti kaip visų akademijos dėstytojų.

Tyrimo metodai. Priklausomų tyrimo objekto kintamuju raiška atskleista taikant apklausos raštu metodą. Jị sudare trys klausimų ir teiginių skalès. Pirma buvo skirta tyrimo dalyvių vertybinèms orientacijoms nustatyti. Konstruodami šią skalę, kurią sudarè 45 vertybès, rèmėmės W. Bielsky ir S. Schwartz (1994) pasiūlyta metodika. Visos vertybės pagal tiriamus požymius buvo suskirstytos i atskiras grupes, kurių iš viso buvo 10. Tai valdžios (prestižas, garbè), pasiekimų (atkaklumas, gebejjimas atlikti užduotis), malonumo (pasitenkinimas gyvenimu), gyvenimo įvairovès (idomus gyvenimas), kryptingumo (laisvè, kūrybiškumas), universalumo (išmintingumas, pažiūru platumas), geranoriškumo (atlaidumas, teisingumas), konservatyvumo (santūrumas), konformiškumo (paklusnumas, savidisciplina) ir saugumo (šeimos saugumas) vertybès. Visos vertybės klausimy- 
ne buvo pateiktos atsitiktine tvarka. Tiriamieji, pasirinkdami vieną iš penkių atsakymo variantu (1 - visiškai nesvarbi, 5 - labai svarbi), turèjo nurodyti, kiek kiekviena vertybė jiems yra svarbi asmeniniame gyvenime.

Antra klausimyno skale buvo skirta dėstytoju nuostatoms dèl aukštosios mokyklos įvertinti. Ji buvo sudaryta remiantis Edinburgo universitete parengtu klausimynu (Peterson, 2003) ir papildyta mūsų pačių teiginiais. Šioje skalèje buvo vertinami tokie dėstytojų požiūrio į akademiją komponentai kaip institucijos visuomeninis vaidmuo miesto bei šalies kontekste, jos valdymas ir vadovybės atsakomybè, dèstytojų sąžiningumas bei jų lojalumas juos idarbinusios institucijos atžvilgiu, akademiniu bei mokslo žinių panaudojimo galimybės, akademinès vertybės ir kt. Visi požiūrio i aukštają mokyklą komponentai sudare atskiras subskales, kuriose teiginių vertinimo kriterijai buvo skirtingi. Antai atsakymai į teiginius apie akademines vertybes buvo vertinami keturių balų sistema (4 balai - labai svarbu, 1 balas - visai nesvarbu), o lojalumo institucija vertinama penkiabale sistema (5 balai — labai ištikimas, 1 balas - nežinau). Tuo tarpu apie dalyvavimą akademiniame gyvenime buvo sprendžiama iš dviejų atsakymo variantų: taip arba ne.

Trečia klausimyno skale buvo siekiama nustatyti dėstytojų identifikavimosi su aukštaja mokykla raišką. Ją sudarydami rèmėmès J. W. Osborne (1997) akademinio identiteto skale. Skalèje išskyrème dvi subskales, iš kurių viena buvo skirta jausminiam, kita - vertinamajam (dalykiniam) komponentui nustatyti. Jas sudare atitinkamai devyni ir aštuoni teiginiai. Kiekvieną iš jų tiriamieji turëjo ìvertinti pažymėdami vieną iš penkių atsakymo variantu (5 - tikrai sutinku, 1 - tikrai nesutinku).

I klausimyną itraukeme ir tokias socialines demografines tyrimo dalyvių charakteristikas kaip lytis, amžius, pedagoginio darbo aukštojoje mokykloje stažas ir mokslinè pedagoginè kvalifikacija (turi mokslinị laipsnị ar ne). Jos tyrimo metu buvo vertinamos kaip nepriklausomi kintamieji.

Tyrimo procedūros. Dėstytojų apklausa buvo vykdoma per 2004 metu pavasario semestrą. Klausimynas atskirais vokais buvo išdalytas akademijos katedroms ir prašyta užpildytas anketas grąžinti nurodytu adresu. Taip buvo siekiama garantuoti tyrimo dalyvių anonimiškumą. Laikas, per kurị turejjo būti grąžintos užpildytos anketos, nebuvo griežtai reglamentuotas, tačiau tyrimo dalyvių prašyta atsakyti kiek galima greičiau. Kitokios skatinimo priemonės nebuvo taikytos.
Visgi dèl psichosocialinès situacijos, susijusios su déstytojų noru dalyvauti apklausoje, kaip jau minèta, ne visos anketos buvo grąžintos.

Statistinè analizè. Statistinè tyrimo duomenu analizè atlikta naudojant programų paketą SPSS for Windows. Aprašomosios statistikos metodais apskaičiuotos îvairių rodiklių skaitinès charakteristikos (vidurkiai, standartinès paklaidos ir kt.). Vertinant apklausos duomenis, buvo skaičiuojamas tiek vidutinis teiginiu balas, tiek procentinis atsakymu i klausimus duomenu skirstinys. Vidutiniu balu buvo išreikšti vertybinių orientaciju duomenys. Tai leido suskirstyti tirtas vertybes pagal jų svarba. Vidutiniu balu buvo vertinami ir identifikavimosi su akademija duomenys. Kiti apklausos duomenys išreikšti procentais. Panaudojant parametrinius metodus, buvo tikrinamos hipotezès apie gautų duomenų vidurkių lygybę. Tais atvejais, kai duomenys išreikšti balais, hipotezėms tikrinti taikytas Stjudento $t$ testas, o vidurkių skirtumas tarp procentinių duomenų buvo tikrinamas naudojant Pirsono chi kvadrato kriterijų. Rezultatai laikyti statistiškai reikšmingais, jeigu paklaidos tikimybès reikšmé $\mathrm{p}<0,05$, esant $95 \%$ patikimumui.

\section{REZULTATAI}

Tyrimo duomenų analizè parodè, kad svarbiausios akademijos dèstytojams yra kryptingumo (vidutinis ịvertinimo balas - 4,28 $\pm 0,5$ ) ir geranoriškumo $(4,23 \pm 0,46)$ vertybès. Kiek mažiau svarbios universalumo $(4,16 \pm 0,5)$, pasiekimu $(4,04 \pm 0,57)$ ir konformiškumo $(4,05 \pm 0,55)$, o mažiausiai svarbios - konservatyvumo $(3,67 \pm 0,69)$ ir valdžios $(3,55 \pm 0,46)$ vertybès.

Lenteleje parodyta akademijos dėstytojų vertybinių orientacijų raiškos priklausomybė nuo lyties, pedagoginès mokslinès kvalifikacijos ir pedagoginio darbo stažo. Iš lentelès duomenų matyti, kad statistiškai reikšmingas skirtumas vertinant konservatyvumo vertybes nustatytas tarp skirtingą pedagoginį darbo stažą turinčiu dèstytojų. Šios vertybès svarbesnès didesni darbo stažą turintiems pedagogams. Kiti lentelès duomenys rodo tik tendencijas. Antai déstytojams, turintiems mokslinius laipsnius, lyginant su neturinčiais, kiek svarbesnès yra universalumo, geranoriškumo ir konservatyvumo vertybès, tuo tarpu pastarieji dažniau nurodè malonumo ir gyvenimo įvairovès vertybes. Tai galètu rodyti, kad jiems svarbūs tiek įvairūs išbandymai, tiek malonumu potyriai. Pasiekimu, kryptingumo ir universalumo vertybės kiek reikšmingesnès dides- 
nị darbo stažą turintiems dèstytojams. Dėstytojai, turintys mažesni staža, dažniau išskiria malonumo ir gyvenimo įvairovès vertybes.

Sugretinus šiuos duomenis pedagoginės mokslinès kvalifikacijos ir darbo stažo grupèse matyti, kad didesni darbo stažą ir mokslinius laipsnius turintys dèstytojai dažniau nei kiti jų kolegos išskiria tas pačias kryptingumo, universalumo, geranoriškumo ir ypač konservatyvumo vertybes, rečiau - malonumo bei gyvenimo įvairovès.

Lyginant duomenis lyties požiūriu, reikšmingo skirtumo nepastebèta, tik konservatyvumo vertybès šiek tiek būdingesnès moterims nei vyrams.

Akademijos dèstytojų požiūrio i̇ aukštosios mokyklos visuomenini vaidmeni duomenų sklaidos analizè parodè: absoliuti dauguma apklaustujuc $(80,3 \%)$ issitikinę, kad aukštoji mokykla turètu paruošti studentus, gebančius konkuruoti darbo rinkoje, tačiau kur kas mažiau jų (42,5\%) pritare teiginiui, kad aukštajai mokyklai svarbu bendradarbiauti su vietinès valdžios atstovais. Nerasta reikšmingo skirtumo vertinant tyrimo dalyvių nuomonę apie aukštosios mokyklos visuomenini vaidmeni nei pagal lyti ar darbo staža, nei pagal jų turimą mokslinę pedagoginę kvalifikaciją. Visgi išryškèjo kai kurios tendencijos. Antai mokslinius laipsnius turintys dèstytojai (59,0\%) dažniau nei jų kolegos be jų $(37,8 \%)$ pažymèjo, kad labai svarbu ruošti studentus, galinčius diskutuoti su valdžioje esančiais asmenimis ir kritiškai vertinti jų sprendimus, o didesnę darbo aukštojoje mokykloje patirti turintys dėstytojai $(51,6 \%)$ labiau nei mažesnès patirties bendradarbiai $(35,7 \%)$ akcentavo bendradarbiavimo su vietos valdžia svarbą.

Apklausos duomenimis, tik 28,8\% tirtų dèstytojų sutinka su teiginiu, kad aukštoji mokykla turètų būti kuo mažiau priklausoma nuo centrinès valdžios. Šiuo požiūriu institucijos autonomijos būtinumą daugiau akcentavo mokslinius laipsnius turintys dèstytojai, palyginti su jų neturinčiais (atitinkamai 35,9 ir 18,9\%). Atsakant į klausimą apie gaunamų lěšu panaudojima, jų nuomonès skyrèsi labiau. Mokslinius laipsnius turintys akademijos darbuotojai dažniau nurode $(61,5$ ir 45,9\%; $\mathrm{p}<0,05$ ), kad institucijos vadovybė privalo nuolat tikrinti, kaip panaudojamos gaunamos lěšos.

Skyrèsi tiriamujų nuomonė dèl aukštosios mokyklos autonomijos ir darbo stažo grupėse. Didesni pedagoginio darbo stažą turintys dèstytojai labiau pritarè nuomonei, kad aukštoji mokykla turètu būti kuo daugiau kontroliuojama iš šalies $(38,1$ ir 16,1\%). Šiuo požiūriu ypač išsiskyrẻ vyrų ir moterų nuomonès. Vyrai dažniau nei moterys įsitikinę, kad aukštoji mokykla turètų būti mažiau kontroliuojama centrinès valdžios $(42,9$ ir $15,0 \%$; $p<0,01)$. Nepaisant suminètų skirtumų, didesnè dalis akademijos dèstytojų linkę nepritarti idejjai, kad aukštosios mokyklos valdymas turètų būti analogiškas pelno siekiančiai organizacijai. Šiai idejjai pritarè tik $34,1 \%$ apklaustujų nepriklausomai nuo darbo stažo ir pedagoginès mokslinès kvalifikacijos.

Atsakymų i klausimus apie dėstytojų tarpusavio santykius analizè parodè, kad tik trečdalis apklaustujų (32,9\%) mano esantys labai sąžiningi bendraudami su kolegomis. Kiek daugiau tokių asmenų yra tarp turinčių mokslinius laipsnius (38,5 ir $24,3 \%)$. Be to, tarp jų yra daugiau tokių, kurie niekada neperžengia institucijos nustatytų teisètumo ribu, lyginant su mokslinio laipsnio neturinčiaisiais (56,4 ir 29,7\%; p < 0,05). Šiuo požiūriu dar ryškesnis skirtumas tarp vyrų ir moterų. Moterys kur kas dažniau nurodè, kad niekada neperžengia nustatytų teisètumo ribų (62,5 ir 22,9\%; p < 0,01). Darbo stažas čia nebuvo svarbiausias veiksnys.

Vertindami dèstytojų požiūrị i mokslo žinių panaudojimą pastebèjome: tik nedidelè dalis tirtujų $(18,8 \%)$ mano, kad labai svarbu šiomis žiniomis aukštajai mokyklai prisidèti prie rajono, kuriame ji yra įsikūrusi, ekonominès plètros. Čia taip pat nerasta ryškesnio skirtumo tarp tiriamuju grupių. Šiek tiek daugiau tirtujų (22,4\%) nurodė, kad aukštajai mokyklai svarbu prisidèti prie visos šalies ekonominès plètros. Tokiai nuomonei labiau pritarè didesni darbo stažą turintys dèstytojai (28,6 ir $16,1 \%)$.

Daugiau nei pusė tiriamuju $(60,5 \%)$ nepriklausomai nuo socialinių demografinių kintamujų sklaidos vieningai pabrèžè, kad labai svarbu akademijoje vykdyti taikomojo pobūdžio mokslinius tyrimus. 39,5\% pritare teiginiui, kad labai svarbu rengti naujas tyrimų metodikas ir diegti novacijas, galinčias duoti materialinès naudos. Toki požiūri labiau palaikè mažesnę nei 10 metų pedagoginio darbo patirti turintys déstytojai (48,4 ir 33,3\%).

Dauguma dèstytoju, išreikšdami savo nuostatas dèl akademiniu vertybių, pritaria tam, kad rengti mokslų daktarus $(96,1 \%)$, atlikti fundamentinius tyrimus (93,4\%), ugdyti studentų akademini ambicingumą (97,4\%), išsaugoti neakivaizdines studijas $(88,2 \%)$ ir organizuoti kvalifikacijos kèlimo kursus jau baigusiems akademiją asmenims $(93,4 \%)$ yra labai svarbu arba svarbu. Suprantama, kad daugiau mokslinius laipsnius turinčių darbuotoju, lyginant juos su jų neturinčiais, pabrè- 


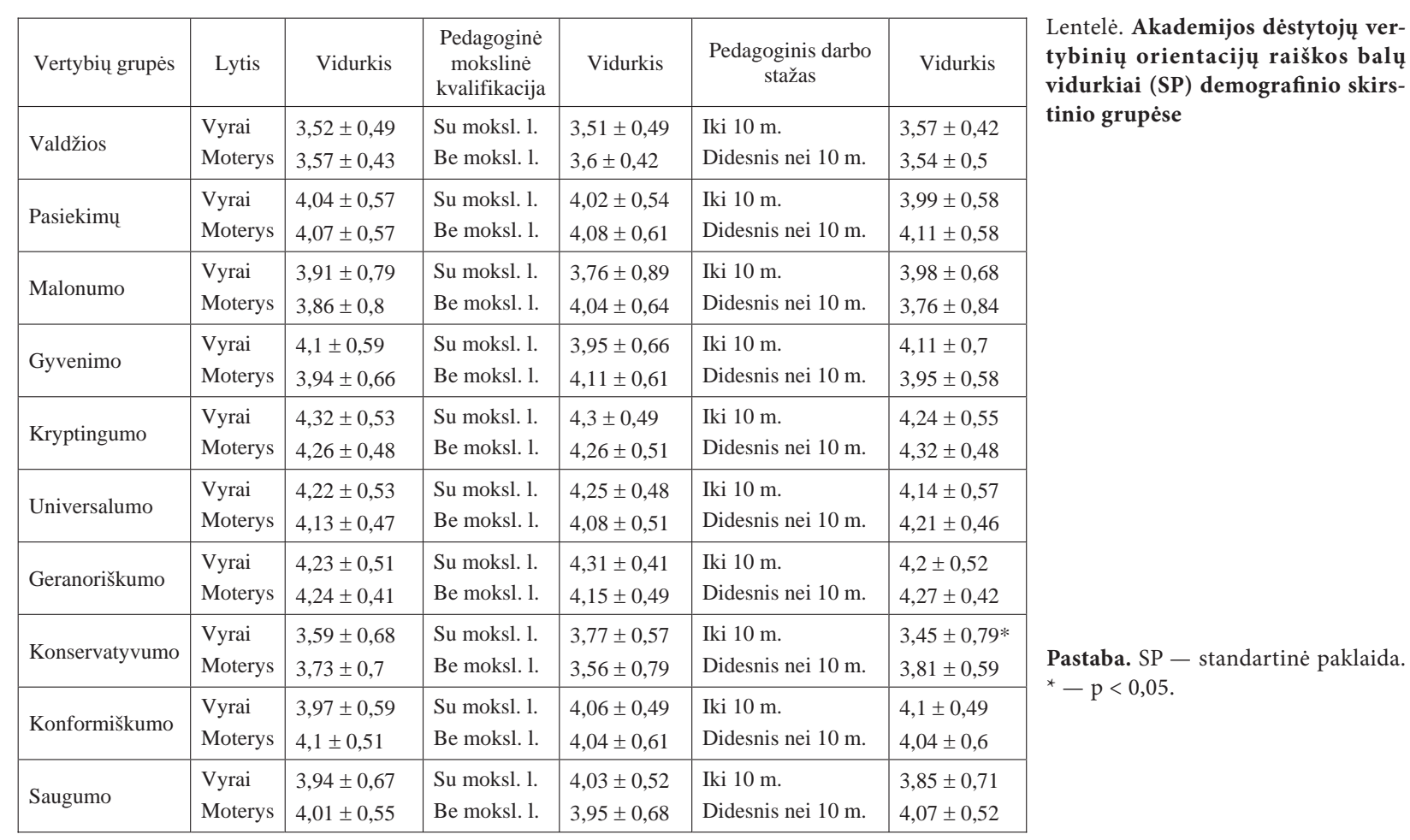

žè: labai svarbu rengti mokslo daktarus (84,6 ir 59,5\%; $\mathrm{p}<0,05)$. Pastebèta tendencija, kad didesnę reikšmę mokslo daktarų rengimui, kaip, beje, ir fundamentinių tyrimu plètotei, skyrè jaunesni darbuotojai, t. y. turintys mažesni nei 10 metu pedagoginio darbo staža.

Dalies apklaustų dėstytojų (44,7\%) nuomone, akademijai nèra svarbu organizuoti moksleiviu profesinio orientavimo kursus. Kiti (45,3\%) mano, kad nebūtina diferencijuoti studijų dalyko užduotis, atsižvelgiant i i studento gyvenimišką patirti. Kiek daugiau dėstytoju (56,0\%) pritaré teiginiui, kad akademijoje turètų būti dèstomi tik tiesiogiai su tam tikra profesija susiję dalykai, o 29,0\% apklaustuju nesutinka su tuo, jog paskaitose galètų dalyvauti ir kitų aukštujų mokyklų studentai, besidomintys dèstomu dalyku. Toks požiūris būdingesnis mokslinio laipsnio neturintiems darbuotojams.

Darbas aukštojoje mokykloje susijęs ne tik su naujausios informacijos kaupimu ir jos perteikimu studentams, bet ir su moksliniais tyrimais, jų rezultatų skelbimu, todèl pasidomèta, kaip šią veiklą vertina tyrimo dalyviai. Apklausos duomenimis, $61,8 \%$ akademijos dèstytojų yra dalyvavę seminaruose ar skaitę paskaitas kitose miesto aukštosiose mokyklose, o 52,6\% tai yra darę ir kitu miestu aukštosiose mokyklose. Daugiau tokiu dėstytoju tarp mokslinius laipsnius turinčiujų (atitinkamai 64,1 ir 40,5\%; p < 0,05). Nemaža dalis apklaustųju $(42,1 \%)$ per pastaruosius trejus metus panašios veiklos vedini pabuvojo užsienio šalyse.
Didžiausias procentas tirtų dėstytojų per minètą trejų metų laikotarpi dalyvavo vietinės $(85,5 \%)$ ir respublikinès $(88,2 \%)$ reikšmès mokslinèse konferencijose. Čia taip pat didesnè dalis tu, kurie turi mokslinius laipsnius $(97,4$ ir 78,4\%; $\mathrm{p}<0,01)$. Dar didesnis skirtumas tarp šių grupių išryškèjo aiškinantis, kiek iš jų dalyvavo mokslinèse konferencijose užsienyje. Tyrimo duomenimis, 74,4\% mokslinius laipsnius turinčių dėstytojų nurodè, kad bent kartą per pastaruosius trejus metus yra dalyvavę tokio pobūdžio renginiuose, o tarp neturinčiu mokslinio laipsnio tokių buvo 45,9\% ( $<<0,01)$.

Kai kuriu skirtumu, analizuojant akademinès bei mokslinès veiklos klausimus, išryškejjo ir lyginant tiriamuosius pagal pedagoginio darbo stažą. Pastebèta tendencija, kad dažniau skaitè paskaitas kitose aukštosiose mokyklose, dalyvavo seminaruose ir konferencijose tie dėstytojai, kurių pedagoginio darbo stažas aukštojoje mokykloje buvo didesnis nei 10 metų. Jie visi nurodè, kad per pastaruosius trejus metus dalyvavo vietinès reikšmès konferencijose, o taip atsakiusių jaunesnių jų kolegų buvo mažiau $-64,5 \%(\mathrm{p}<0,01)$. Kita vertus, kiek daugiau pastaruju, t. y. turinčių mažesnį nei 10 metų staža, nurodè, kad dalyvavo seminaruose ar skaitė paskaitas užsienio šalyse (48,4 ir 40,5\%).

Didesnè dalis apklaustų dėstytojų (63,2\%) yra konsultavę kūno kultūros ir sporto darbuotojus. Čia taip pat išryškèjo stažo ir mokslinès kvalifikacijos svarba. Daugiau konsultuoti teko turintiems mokslinius laipsnius $(79,5$ ir 45,9\%; $\mathrm{p}<0,01)$ ir didesnio 
pedagoginio darbo stažo $(73,8$ ir 48,4\%; $\mathrm{p}<0,05)$ akademijos darbuotojams. Akivaizdžiai išsiskyrè vyrų ir moterų atsakymai: dažniau kitus asmenis yra konsultavę vyrai (80,0 ir 50,0\%; $\mathrm{p}<0,01)$.

Svarbesni nagrinėjamos temos aspektu turètu būti duomenys, rodantys, kaip tyrimo dalyviai vertina instituciją, kurioje dirba, arba, kitaip tariant, kaip jie identifikuojasi su akademija. Būtina pastebèti, kad literatūroje identitetas neretai siejamas ar net tapatinamas su izvaizdžiu. Nurodoma, pavyzdžiui, kad tai, kaip institucijos reprezentuoja save, labai priklauso nuo jų tapatumo, t. y. nuo to, kiek jos yra integruotos ir koks jų institucinis „aš“, o i̇vaizdis suformuoja žmonių požiūrį i juos pačius, t. y. kokie jie yra, kokiais norètu būti, ko jie nori ir ką ketina veikti (Taljūnaitè, 2001). Daugeliu atvejų organizacinis identitetas bei iqvaizdis sutampa, nors gali ir skirtis. Tyrimo metu bandėme nustatyti du dėstytojų identiteto su akademija lygius: jausmini (ji siejome su akademijos vertinimu, didžiavimusi ja, jos įvaizdžiu aplinkiniu akimis, savijauta darbe ir kt.) ir dalykini (pastarasis sietinas su darbuotoju darbo sąlygomis, bendravimo su studentais ypatumais, tobulinimosi galimybėmis ir kt.). Abieju identifikavimosi su akademija lygių atžvilgiu visus tyrimo dalyvius suskirstėme $\mathfrak{i}$ dvi grupes: labai susitapatinusių ir silpnai susitapatinusių. Šias grupes dar būtų galima ịvardyti kaip palankiai ar ne taip palankiai suvokiančias akademijos identiteta, tačiau toks skirstymas būtų sąlygiškas, nes negalima griežtai nubrèžti ribos tarp palankiai ir ne taip palankiai suvokto identiteto.

Tyrimo rezultatai parodè, kad daugumai apklaustų dėstytojų $(77,6 \%)$ būdingas stiprus jausminis identifikavimasis su akademija. Pastebèta tendencija, kad toks identifikavimasis kiek būdingesnis tiems dèstytojams, kurie turi mokslinius laipsnius (82,1 ir 73,0\%), taip pat vyrams, lyginant juos su moterimis (54,3 ir 47,5\%). Šio identiteto lygmens komponentų analizès duomenimis, 64,4\% tirtų akademijos dėstytojų didžiuojasi dirbdami joje, tad jeigu reikètų rinktis iš naujo, $69,7 \%$ vèl ją pasirinktų. Dauguma tyrimo dalyvių (78,6\%) akademijos sèkmę siejo su savo sèkme, o $86,9 \%$ issitikinę, kad jie čia laiko veltui neleidžia. Aplinkinių nuomonė apie akademiją domina 79,0\% apklaustų dėstytojų, o 58,4\% jų mano, kad joje yra žmonių, kuriais galėtų pasitikèti.

Jausminio identifikavimosi lygmuo, matyt, nėra susijęs su dalykiniu lygmeniu, nes pastarojo identifikavimosi požiūriu labai susitapatinusių su akademija buvo tik 27,6\% apklaustų dèstytojų.
Kiek daugiau tokių buvo tarp turinčiujų mokslinius laipsnius (33,3 ir 21,6\%). Mažesnè dalis tirtų dèstytoju (44,8\%) darbo sąlygas vertina gerai. Panašus jų procentas $(47,4 \%)$ nepritaria nuomonei, kad akademija atrodo prasčiausiai, lyginant ją su kitais universitetais. Ne visus dèstytojus tenkina santykiai su studentais (59,2\%). Dar kukliau jie vertina akademijos biblioteka, kurioje norètu rasti viską, ko jiems reikia $(27,6 \%)$. Nedidelè dalis apklaustujų (34,2\%) mano, kad akademijoje galima atlikti rimtus mokslinius tyrimus. Požiūrio i biblioteką ir i galimybę atlikti rimtus mokslinius tyrimus skirtumas priklauso nuo dėstytojo pedagoginio darbo stažo. Bibliotekos paslaugomis labiau patenkinti didesni darbo stažą turintys dèstytojai (33,3 ir 19,4\%), tačiau turintys mažesni stažą dažniau nurodo, kad akademijoje galima atlikti rimtus mokslinius tyrimus (38,7 ir 28,6\%).

Nèra optimistinès prognozės tirtuju požiūriu ir dèl akademijos ateities perspektyvų. Apklausos rezultatai rodo, kad tik 28,9\% dèstytojų issitikinę geromis jos perspektyvomis, t. y. jie tikisi, kad akademija taps aukšto lygio sporto universitetu. Beje, tokia perspektyva labiau tiki mokslinius laipsnius (35,9 ir 21,6\%) ir didesni darbo stažą (33,3 ir 25,8\%) turintys dèstytojai. Taip pat pastebèta, kad tie dèstytojai, kuriu jausminė identifikacija su akademija yra stipri, optimistiškiau vertina ir jos perspektyvas, palyginti su tais, kurių analogiška identifikacija yra silpna (46,2 ir 10,8\%; p < 0,001). Dar didesnis požiūrio į akademijos perspektyvas skirtumas išryškèjo lyginant tiriamuosius pagal jų dalykinę identifikaciją su akademija. Tie dėstytojai, kurių dalykinè identifikacija buvo stipri, kur kas teigiamiau vertina akademijos perspektyvas, palyginti su tais, kuriu dalykine identifikacija su akademija buvo ne tokia stipri $(52,8$ ir 7,5\%; p < 0,001). Visgi 31,6\% apklaustų dėstytojų akademijos perspektyvas vertina pesimistiškai, t. y. mano, kad akademija taps kito universiteto fakultetu arba kolegija.

Analizuodami duomenis pastebejome ir daugiau sąsajų tarp dėstytojų identifikavimosi su akademija raiškos ir jų požiūrio ị akademiją. Antai stipriau su akademija susitapatinę tiriamieji yra jai lojalesni, palyginti su tais, kuriu identifikavimasis su akademija nebuvo toks ryškus $(69,2$ ir $29,7 \%$; p < 0,01). Logiška manyti, kad lojalesni darbuotojai turètų labiau laikytis nustatytų taisyklių. Rezultatai patvirtino daromą prielaidą: 53,8\% stipriau su akademija susitapatinusių darbuotojų, lyginant juos su 32,4\% silpniau susitapatinusiuju, nurodè, kad 
jie niekada nėra peržengę nustatytų teisètumo ribu ( $<<0,05)$. Be to, kad taip kartais nutinka, nurodè 5,1\% pirmujų ir 18,9\% pastarujų. Palankesni ivaizdị apie akademiją turintys dèstytojai labiau nei tie, kurių šis įvaizdis nėra toks ryškus, pasisako už tai, kad akademijai svarbu rengti studentus, gebančius kritiškai vertinti ivykius ir kitų priimamus sprendimus (atitinkamai 64,1 ir 32,4\%; p < 0,01). Tarp šiu grupių išryškèjo ir požiūrio ị fundamentinių tyrimų svarbą skirtumas. Jų svarbą dažniau akcentavo labiau su akademija identifikavęsi dèstytojai (59,0 ir 27,0\%; p < 0,01). Jie taip pat labiau pabrèžè mokslo daktarų rengimo akademijoje svarbą (86,1 ir $60,0 \%$; $<<0,05$ ).

\section{REZULTATŲ APTARIMAS}

Apibūdinus žmogaus vertybes kaip pažintinius konstruktus, paaiškinančius individualius skirtumus ir jų priklausomybę nuo asmens gyvenimo tikslu, elgesio principų ir prioritetu (Renner et al., 2003), galima manyti, kad akademijos dėstytojai gyvenimo prioritetais laiko išmintinguma, pažiūru platumą ir gebejjimą atlikti užduotis. Šios vertybės rodo svarbiausius akademinius (kaip ir apskritai gyvenimo) prioritetus. Mat norint kažką pasiekti, neužtenka laukti kitų malonès, būtina atkakliai siekti užsibrezžto tikslo, o tam reikia ne tik pastangu, bet ir išminties. Kita vertus, dirbant akademini ir mokslini darbą, labai svarbu aprèpti visapusišką tam tikros srities žinių spektrą, todèl asmuo turi būti platesnių pažiūrų. Savo ruožtu pažiūrų platumas rodo asmens išsilavinimą. Ne paskutineje vietoje pagal reikšmę yra ir saugumo vertybès, ypač tarp mokslinius laipsnius turinčių dėstytoju, nes ju gyvenime pasiekta tam tikra padètis gali laiduoti didesni saugumo bei tvirtumo jausmą.

Akademijos dėstytojai supranta, kad labai svarbu paruošti ne bet kokius specialistus, o tokius, kurie gebėtu rasti savo vietą darbo rinkoje. Tai aktualu ne tik jiems, bet ir akademijai, nes kuo daugiau jos absolventų suranda darbą pagal specialybę, tuo geriau studiju programos atitinka darbo rinkos poreikius. Visgi akademiją vertinant šiuo požiūriu, reikia atsižvelgti į tai, kad dalis studentu studijuoja tam tikrą specialybę tik norèdami gauti aukštojo mokslo diplomą. Tą patvirtina kitu tyrimų rezultatai (Kardelis, Karanauskienė, 2003). Be to, yra nustatyta, kad aukštesnio akademinio identiteto studentai išsiskiria ir studijų motyvacija: jie labiau siekia žinių nei pažymių (Karanauskienė, Kardelis, 2005). Galima daryti išvadą, kad tų absolventu, kurie studijas renkasi nebūdami ịsitikinę dèl darbo rinkos reikalavimų ir motyvuoti susirasti konkrečią darbo vietą pagal igytą specialybę, kompetencija neatitinka darbo rinkos paklausos.

Akademijos prestižą galima įvertinti geriau atsižvelgiant i joje atliekamų mokslinių tyrimų svarbą, mokslininkų rengimą, todèl ypač svarbu, kaip patys dèstytojai vertina šią veiklą. Iš tyrimo duomenu matyti, kad akademijos dèstytojai gerai supranta šių veiksnių svarbą. Logiška ir tai, kad mokslo daktarų rengimo svarbą labiau akcentavo mokslinius laipsnius turintys dèstytojai, nes tai visų pirma rodo jų kompetenciją mokslo srityje, o antra, tai turi ryši ir su naujais moksliniais tyrimais. Gerai yra tai, kad tiek moksliniu tyrimu plètrai, tiek ìvairių novaciju diegimui ir jų komerciniam panaudojimui labiau pritare jaunesni dėstytojai, nes nuo jų daugiausia priklausys mokslinès veiklos perspektyvos. Tai yra susiję su jų profesinès karjeros raida, būtent su jos įsitvirtinimo laikotarpiu (25-44 m.), kada asmuo nori užsigarantuoti tam tikrą poziciją isitvirtinti darbe ir siekti karjeros. Tuo tarpu profesinès karjeros raidos išlaikymo laikotarpiu (45—64 m.) būdingesnis prisitaikymas norint išsaugoti pasiektas pozicijas (Super et al., 1996).

Pastaruoju metu vis plačiau kalbama apie studijų ir mokslo vienovę, todèl svarbu ne tik kaupti dalykines ir mokslo žinias, bet perteikti jas ivvairių seminarų metu ir skaitant paskaitas akademijos bei kitų universitetų studentams. Tyrimo rezultatai parodé, kad daugiau nei pusė apklaustų dèstytoju yra skaitę paskaitas ar dalyvavę seminaruose kitose aukštosiose mokyklose. Kyla klausimas: ar tai pakankamas skaičius? Be to, dažniau skaite paskaitas ir dalyvavo seminaruose mokslinius laipsnius turintys dèstytojai. Tai suprantama, nes norint skaityti paskaitas, ypač kituose universitetuose, būtina turèti atitinkamą kompetencija.

Kiekvienas universitetas siekia kaip galima didesnès autonomijos, kad galètų realizuoti akademines laisves. Visgi visiška autonomija vargu ar imanoma, nes, pasak M. Spiro (2003), ji priklauso nuo kultūrinių sąlygų ir politinès šalies sistemos. Taip pat aišku, kad universitetai neturès ir finansinès autonomijos, tad ir toliau išliks centrinès valdžios kontroliuojami. Apklausos duomenis išnagrinejjus šiuo aspektu, galima daryti išvadą, kad daugumą dėstytojų tenkina akademijos santykis su centrine valdžia, tačiau mokslinius laipsnius turintys dėstytojai norètų didesnès autonomijos. Be to, pusė tyrimo dalyviu yra įsitikinę, kad akade- 
mijos vadovybė turètų nuolat tikrinti turimų lěšų panaudojimą. Toks noras suprantamas, nes jau ne pirmi metai visos aukštosios mokyklos skundžiasi nepakankamu finansavimu. Nuolatos susiduriama su lèšu trūkumu, ribojančiu dèstytoju poreikių tenkinimą, todèl būtina jas kontroliuoti.

Šiuolaikinis dèstytojas turi gebėti ne tik perteikti naujausias žinias studentams bei vykdyti mokslinius tyrimus, bet privalo turèti ir vadybiniųžiniu, nes vis labiau akcentuojama, kad patys universitetai dali lěšų turi užsidirbti. Tai leidžia kelti prielaidą, kad universitetams galètų būti taikomi verslo organizacijų valdymo principai. Visgi tai ir lieka tik prielaida arba retorinis klausimas, nes dauguma akademijos dèstytojų apskritai nepritaria tokiai idejjai. Nepritaria jie ir tai minčiai, kad savo sukauptomis mokslo žiniomis universitetai galètų prisidèti prie regiono ar šalies ekonominès plètros. Tuo tarpu literatūroje vis dažniau pabrèžiamas aukštojo mokslo indèlis i regioninès ir nacionalinès ekonomikos plètrą. Toks aukštojo mokslo vaidmens išskirtinumas dažnai yra siejamas su žinių apie ekonomikos augimą svarba ir daroma prielaida, kad ịvairių verslo šakų konkurencingumas priklauso nuo darbuotojų gebejjimo diegti novacijas ir prisitaikyti prie nauju informacijos bei komunikacijos technologiju. Versle vis labiau reikia aukštos kvalifikacijos specialistu̧, todèl būtina turèti galimybę naudotis pažangiais universitetų mokslo lobynais (Bridges, 2004).

Kalbant apie aukštają mokyklą, nemažiau svarbu atsakyti i klausimą: koks yra bendravimas tarp pačių dèstytojų ir koks jų santykis su universitetu? Tyrimo duomenys rodo, kad tik trečdalis dèstytojų mano esantys labai sąžiningi bendraudami su kolegomis. Panašus jų skaičius teigé niekada neperžengiantys teisètumo ribų. Pastaruju labiau laikosi moterys nei vyrai. Tai rodo, kad akademijos bendruomenèje dar trūksta tiek tarpusavio santykiu, tiek požiūrio ị darbą vidinès darnos.

Teigiamai reikètu vertinti ir daugiau kaip dvieju trečdalių dèstytojų stiprų jausminị identifikavimąsi su akademija. Tai rodo, kad dauguma dėstytoju palankiai vertina akademija, darbe jaučiasi gerai ir nėra abejingi tam, ką apie akademiją kalba aplinkiniai. Gal taip yra dèl to, kad daugelis akademijos dèstytoju yra šios mokyklos auklètiniai, ir nemaža jų gyvenimo dalis praleista joje. Kur kas mažesnè apklaustujų dalis susitapatina su akademija dalykine prasme, o tai reiškia, kad jie nėra patenkinti darbo sąlygomis, bibliotekoje sukaupta literatūra, ne visada juos tenkina ir santykiai su studentais. Silpna dalykinè identifikacija su akademija lemia tai, kad dalis dėstytojų ne taip palankiai vertina mokslinių tyrimų svarbą, aukštosios mokyklos perspektyvas. Tai rodo dėstytojų santykių su akademija reikšmingumą, nuo kurio priklauso ne tik jų nuostatos ir elgesys, bet ir studiju kokybè. Tiriant akademijos studentų identifikavimosi su studijomis raišką nustatyta, kad aukštesnio akademinio identiteto studentai palankiau vertina studijų sąlygas, studentų ir dėstytojų santykius bei galimybę atlikti rimtus mokslinius tyrimus, tačiau kritiškiau nei žemesnio akademinio identiteto studentai vertina fizinę akademijos aplinką (Karanauskienė, Kardelis, 2005). Tai rodo, kad egzistuoja glaudus ryšys tarp studentų akademinio identiteto ir emocinio bei vertybinio naujos socialinès aplinkos (akademijos) reikšmingumo: kuo aukštoji mokykla studentui svarbesnè, tuo aukštesnis jo akademinio identiteto lygmuo. Vadinasi, modeliuojant kuo priimtinesnes įvairių studentų socialines psichologines mokymosi sąlygas, galima būtų skatinti jų akademinį identiteta, kartu gerinti ir studijų kokybę. Nemažiau svarbios šiame procese gali būti dèstytojų nuostatos dèl studijų proceso bei jų identifikavimosi su akademija raiška. Mat edukacineje sistemoje, kurioje mokosi studentai, pastarieji veiksniai gali paveikti jų akademinio identiteto formavimąsi ir studijų sėkmę.

\section{IŠVADOS}

Tyrimo rezultatai leidžia teigti, kad kelta prielaida apie dèstytojų požiūrio į akademiją ir akademines vertybes priklausomybę nuo pedagoginès mokslinès kvalifikacijos pasitvirtino. Tų dėstytojų, kurie turi mokslinius laipsnius, požiūris į akademiją ir i akademines vertybes yra pozityvesnis. Vadinasi, tiek mokslinių tyrimų plètra, tiek mokslo daktarų rengimas yra vieni iš pagrindinių akademijos prioritetų. Tai savo ruožtu galètų pakeisti ne tik dėstytojų turinčių skirtingas nuostatas dèl akademijos, santyki, bet ir akademijos santykị su visuomene.

\section{LITERATŪRA}

Bielsky, W., Schwartz, S. (1994). Values and personality. European Journal of Personality, 8, 163-181.

Bridges, D. (2004). Higher education and economic development. Socialiniai mokslai, 2 (44), 7-16.

Gynnild, V. (2003). An action theoretical approach to learning in higher education. Socialiniai mokslai, 5 (42), $51-56$.

Janiūnaitė, B., Gudaityte, D. (2003). Contemporary higher education as a catalyst of social innovation in the context of societal transformations. Socialiniai mokslai, 5 (42), 7-16. 
Karanauskienė, D., Kardelis, K. (2005). The relationship between students' academic identity and academic achievements. Socialiniai mokslai, 1 (47), 62-70.

Kardelis, K., Karanauskienè, D. (2003). Studentu suvokto aukštosios mokyklos identiteto bei įvaizdžio ir jų veiklos motyvacijos sąsaja. Ugdymas. Kūno kultūra. Sportas, 4 (49), 25-30.

Kardelis, K. (2002). Moksliniu tyrimu metodologija ir metodai. Kaunas: Judex.

Markevičienè, A. (2004). Controversies at the service university: Academia and market. Socialiniai mokslai, 2 (44), 29-36.

Osborne, J. W. (1997). Identification with academics and academic success among community college students. Community College Review, 25 (1), 59-69.

Peterson, L. (2003). The survival of the democratic intellect: Academic values in Scotland and England. Higher Education Quarterly, 57 (1), 67-93.

Renner, W., Salem, J., Alexandrowicz, R. (2004). Human values as predictors for political, religious and healthrelated attitudes: A contribution towards validating the Austrian value questionnaire by structural equation mode- ling. Social Behavior and Personality, 32 (5), 477-490. Scott, P. (2003). Challenges to academic values and the organization of academic work in a time of globalization. Higher Education in Europe, 28 (3), 295-306.

Spiro, M. (2003). Academic values and academic work in the era of globalization: The case at Albanian universities. Higher Education in Europe, 28 (3), 312-315.

Super, D. E., Savickas, M. L., Super, M. C. (1996). The life-span, life-space aprroach to careers. In D. Brown, L. Brooks (Eds.), Career Choice and Development (pp. 121-178). San Francisco: Jossey-Bass Publisher.

Taljūnaitè, M. (2001). Valstybès instituciju ìvaizdis ir organizacine elgsena. Vilnius: Lietuvos teisès universitetas.

Valiuškevičiūtė, A., Druskyte, R., Mikutavičienė, J. (2004). Universitetinių studijų kokybės vertinimas: akademinès bendruomenès požiūris. Aukštojo mokslo kokybe, 1 , $38-59$.

Verri, G. (2003). Challenges to academe in a time of globalization. Higher Education in Europe, 28 (3), 307-311.

Želvys, R. (2003). Reform of higher education in Lithuania: Moving towards decentralization or state control. Socialiniai mokslai, 5 (42), 17-20

\title{
MANIFESTATION OF VALUE ORIENTATIONS OF LAPE TEACHERS AND THEIR ATTITUDES TOWARDS ACADEMY IN THE CONTEXT OF INTERRELATION OF HIGHER EDUCATION AND SOCIETY DEVELOPMENT
} Saulius Šukys, Kęstutis Kardelis, Albertas Skurvydas

Lithuanian Academy of Physical Education, Kaunas, Lithuania

\begin{abstract}
The research deals with the peculiarities of teacher value orientations and their attitudes towards the institution of higher education. To tackle the problem question 90 teachers of the Lithuanian Academy of Physical Education were interviewed. The value orientations of teachers were measured with a scale of tenvalue groups (all in all 45 values). While assessing teachers' attitudes towards the Academy such attitude components as the social role of the institution in the context of the city and the state, the responsibility of its management and leadership, intercommunication of teachers, possibilities to apply academic and scholarly knowledge, as well as teachers' attitudes towards academic values were estimated. The research also established teachers' identification with their higher school.

The research results indicated that the life priorities of the Academy's teachers were wisdom, liberality and ability of persistent task accomplishment. The results of the attitudes towards the Academy and the academic values revealed that the Academy's teachers apprehended the importance of research work and scientist education. They also accepted the significance of the preparation of specialists capable of adapting and competing in the labor market. More than a half of the sample had presented seminars or participated in them at various institutions of higher education. Though the majority of teachers expressed favorable attitudes towards the Academy and are not indifferent to it, they were less satisfied with their labor conditions and communication with students. The relation between the more favorable attitudes towards the Academy and the teachers' pedagogical and scientific qualifications was noted, too. So, we can claim that the main priorities of the Academy are the development of research work and the education of scientists.
\end{abstract}

Keywords: higher school, teachers' value orientations, their attitudes towards the institution of higher education and academic values.

Gauta 2005 m. rugsejjo 21 d.

Received on September 21, 2005

Saulius Šukys

Lietuvos kūno kultūros akademija

(Lithuanian Acaademy of Physical Education)

Sporto g. 6, LT-44221 Kaunas

Priimta 2005 m. gruodžio 28 d.

Accepted on December 28, 2005

Lietuva (Lithuania)

Tel +370 37302637

E-mailsml.saulius@mail.lt 